Jurnal Pendidikan, Vol. 8, No. 2, Tahun 2020

ISSN: 2337-7607 e-ISSN: 2337-7593

\title{
Penerapan Metode Pembelajaran Simulasi untuk Meningkatkan Aktivitas dan Prestasi Belajar Mata Kuliah TEYL Mahasiswa Semester VI Pendidikan Bahasa Inggris FKIP Universitas Pendidikan Muhammadiyah Sorong
}

\author{
Nursalim, M.Pd. \\ Program Studi Pendidikan Bahasa Inggris \\ Universitas Pendidikan Muhammadiyah Sorong \\ adennursalim@gmail.com
}

\begin{abstract}
Abstrak. Penelitian ini bertujuan untuk meningkatkan keaktifan dan prestasi belajar mahasiswa dengan penerapan metode simulasi dalam mata kuliah Teaching English For Young Learners. Penelitian ini merupakan penelitian tindakan kelas. Setting penelitian adalah mahasiswa reguler semester VI, berjumlah 30 orang mahasiswa yang mengambil mata kuliah Teaching English For Young Learners. Rancangan penelitian melibatkan dosen sebagai peneliti utama dan sekaligus sebagai pelaku tindakan, dosen pengamat dan mahasiswa sebagai subyek didik. Cara penelitian dilakukan melalui : 1. perencanaan, 2. implementasi tindakan kelas, 3. pemantauan dan evaluasi, 4. analisis dan refleksi, 5. penyimpulan hasil. Pengumpulan data menggunakan observasi, dokumentasi, wawancara dan angket : Uji keabsahan data menggunakan triangulasi metode dan sumber. Penelitian tindakan ini dengan menerapkan metode simulasi dalam pembelajaranTeaching English For Young Learners. Hasil dari penelitian tindakan ini adalah 1) Penerapan metode pembelajaran simulasi dapat meningkatkan aktifitas mahasiswa. Terjadi peningkatan aktivitas belajar dari siklus I ke siklus II, dan dari siklus II ke siklus III. 2) Penerapan metode pembelajaran simulasi dapat mengoptimalkan prestasi belajar mahasiswa. Prestasi belajar mahasiswa mengalami peningkatan dari prestasi belajar siklus I ke siklus II, dan dari siklus II ke siklus III.
\end{abstract}

Kata kunci: Simulasi, Prestasi Belajar, Universitas Pendidikan Muhammadiyah Sorong

Abstract. This study aims to improve the activeness and learning achievement of students by applying simulation methods in Teaching English For Young Learners courses. This research is a class action research. The research setting was regular semester VI students, totaling 30 students who took Teaching English For Young Learners courses. The research design involves the lecturer as the main researcher and at the same time the perpetrators of the action, the observer lecturer and students as the subject of the students. The way the research is carried out through: 1. planning, 2. implementation of class actions, 3. monitoring and evaluation, 4. analysis and reflection, 5. summarizing results. Data collection uses observation, documentation, interviews and questionnaires: Test the validity of the data using triangulation of methods and sources.Research this action by applying simulation methods in teaching Teaching English For Young Learners. The results of this action research are 1) The application of simulation learning methods can increase student activities. An increase in learning activities from cycle I to cycle II, and from cycle II to cycle III. 2) Application of simulation learning 
methods can optimize student learning achievement. Student learning achievement has increased from learning achievement cycle I to cycle II, and from cycle II to cycle III.

\section{Keywords: Simulation, Sorong Muhammadiyah Education University}

\section{Pendahuluan}

Teaching English For Young Learners (TEYL) merupakan mata kuliah wajib tempuh bagi mahasiswa pendidikan Bahasa Inggris. Mata kuliah ini memberi gambaran kepada mahasiswa bagaimana seorang guru ke depan dalam mengajarkan Bahasa Inggris bagi anak anak di Sekolah Dasar atau pemula.

Perkuliahan ini bertujuan agar mahasiswa kenal dan mampu strategi pengajaran bahasa Inggris untuk anak-anak sebagai suatu pengetahuan, wawasan, kesadaran dan Keterampilan.

Muatan materi yang diulas meliputi konteks pembelajaran bahasa Inggris bagi anak-anak, bagaimana seorang anak belajar bahasa, perkembangan bahasa anak, karakteristik anak sebagai pembelajar bahasa, pengembangan pembelajaran bahasa Inggris untuk anak, sumber belajar dan teknologi pembelajaran untuk anak, penilaian pembelajaran untuk anak. Perkuliahan diselenggarakan melalui kegiatan perbelajaran di dalam kelas, pengamatan atau observasi lapangan, tugas-tugas terstruktur baik di kelas maupun di dalam kelas. Evaluasi dilakukan berdasarkan partisipasi kelas, tugas-tugas, dan ujian akhir semester.

Adapun capaian dalam pembelajaran diantaranya untuk memperkuat sikap, pengetahuan dan keterampilan mahasiswa. Proses pembelajaran dapat dikatakan berhasil jika semua aspek pembelajaran dapat saling mendukung dalam menciptakan situasi yang kondusif untuk kegiatan pembelajaran. Proses pembelajaran yang baik tentunya akan berpengaruh pada pemahaman mahasiswa terhadap materi yang disampaikan dosen. Sasaran utama dari kegiatan pembelajaran terletak pada proses belajar peserta didik, yang harus mengutamakan belajar mahasiswa secara aktif, karena sasaran pendidikan adalah proses pembelajaran mahasiswa, bukan semata-mata mengukur hasil belajar mahasiswa. Namun dalam proses pembelajaran masih saja ditemukan kendala-kendala dalam kegiatan pembelajaran.

Penerapan metode ceramah bagi dosen merupakan metode paling mudah untuk mengelola kelas dan bisa mengejar target materi yang harus diselesaikan. Dengan metode ceramah peranan dosen sangat dominan, dosen sebagai subjek penyampai informasi, dosen merupakan pusat perhatian, dosen lebih banyak berbicara sementara mahasiswa mendengarkan atau mencatat halhal yang penting. Komunikasi yang terjadi cenderung satu arah di mana alat komunikasi yang utama digunakan adalah berbicara. Karena komunikasi yang terjadi hanya satu arah, maka proses belajar mengajar menjadi kurang menarik bahkan membosankan. Meskipun demikian masih banyak yang tetap menggunakan metode ceramah tanpa variasi lain.

Berdasarkan hasil survei pada saat pra observasi yang dilakukan peneliti pada mata pelajaran TEYL diketahui bahwa salah satu kendala yang dirasakan oleh dosen dalam pembelajaran TEYL adalah kurangnya kerjasama antar mahasiswa saat pembelajaran berlangsung dan pada saat diskusi kelas, sementara kemampuan mahasiswa tidak sama. Dengan adanya kerja sama diharapkan mahasiswa yang cakap akan membantu mahasiswa yang kurang cakap, demikian pula mahasiswa yang kurang cakap berani bertanya pada mahasiswa yang cakap dalam pembelajaran TEYL.

Berdasarkan pengamatan dan interview dari beberapa mahasiswa, diperoleh kenyataan bahwa : 1.Pada umumnya tingkat partisipasi mahasiswa dalam proses pembelajaran rendah, 2. Mahasiswa pasif dan kurang bersemangat dalam proses pembelajaran, 3. Mahasiswa kurang 
mampu berkomunikasi secara lisan, sehingga jarang menyampaikan gagasan, 4. Mahasiswa jarang mengajukan petanyaan.

Berdasarkan permasalahan tersebut, maka melalui penelitian tindakan kelas ini peneliti bermaksud mencari alternatif dan solusi. Metode pembelajaran yang akan digunakan dalam penelitian ini adalah menerapkan metode simulasi. Metode pembelajaran simulasi dapat menggambarkan keadaan sebenarnya dari suatu keadaan, penyederhanaan dari suatu fenomena di dunia nyata. Simulasi adalah suatu tiruan atau perbuatan berpura-pura saja (Sunaryo, 1989:137). Dalam setiap bentuk simulasi akan terjadi hal-hal sebagai berikut: (1) para pemain memegang peranan yang mewakili dunia nyata, dan juga membuat keputusan-keputusan dalam mereaksi penilaian mereka terhadap setting yang meeka temukan sendiri, (2) mereka mengalami perbuatan-perbuatan tiruan yang berhubungan dengan keputusan-keputusan mereka dan penampilan umum mereka, (3) mereka memonitor hasil kegiatan masing-masing, dan diarahkan untuk merefleksi terhadap hubungan antara keputusan-keputusan mereka sendiri dan konsekuensi-konsekuensi akhir yang menunjukkan gabungan dari berbagai perbuatan.

Pembelajaran simulasi mempunyai beberapa tujuan yaitu: 1) tujuan langsung yang terdiri dari: a) untuk melatih keterampilan tertentu, baik yang bersifat profesional maupun bagi kehidupan sehari-hari, b) untuk memperoleh pemahaman tentang suatu konsep atau prinsip, c) untuk latihan memecahkan masalah 2) tujuan tidak langsung a) Untuk meningkatkan aktivitas belajar dengan melibatkan dirinya dalam mempelajari situasi yang hampir serupa dengan kejadian yang sebenarnya. b) Untuk memberikan motivasi belajar karena anak sangat menarik dan menyenangkan anak-anak. c) Melatih anak bekerja sama dalam kelompok dengan lebih efektif. d) Menimbulkan dan memupuk daya kreatif anak.e) Melatih anak untuk memahami dan menghargai peranan anggota lain.

Karena aktivitas belajar itu banyak sekali macamnya maka para ahli mengadakan klasifikasi atas macam-macam aktivitas. Paul D Dierich dalam Oemar Hamalik, (2001), membagi kegiatan dalam 8 kelompok yaitu: 1) kegiatan-kegiatan visual : Membaca, melihat gambar-gambar, mengamati eksperimen, demonstrasi, pameran, dan mengamati orang lain bekerja atau bermain. Ini terkait dengan kemampuan indera penglihatan. 2) kegiatan-kegiatan lisan (oral) terdiri dari: Mengemukakan suatu fakta atau prinsip, menghubungkan suatu kejadian, mengajukan pertanyaan, memberi saran, mengemukakan pendapat, wawancara, diskusi, dan ineterupsi. 4) kegiatan-kegiatan mendengarkan terdiri dari: mendengarkan penyajian bahan, mendengarkan percakapan atau diskusi kelompok, mendengarkan suatu permainan, mendengarkan radio. 5) kegiatan-kegiatan menulis terdiri menulis cerita, menulis laporan, memeriksa karangan,bahanbahan kopi, membuat rangkuman, mengerjakan tes, dan mengisi angket. 6) kegiatan-kegiatan menggambar terdiri dari: Menggambar, membuat grafik, chart, diagram peta, dan pola. 7) kegiatan-kegiatan metrik terdiri dari melakukan percobaan, memilih alat-alat, melaksanakan pameran, membuat model, menyelenggarakan permainan, menari dan berkebun. 8) kegiatankegiatan mental terdiri dari: merenungkan, mengingat, memecahkan masalah, menganalisis, faktor-faktor, melihat, hubungan-hubungan, dan membuat keputusan. 9) kegiatan-kegiatan emocional minat, membedakan, berani, tenang dan lain-lain. Kegiatan-kegiatan dalam kelompok ini terdapat dalam semua jenis kegiatan dan overlap satu sama lain.

Berbagai teori, penelitian dan pelaksanaan pembelajaran membuktikan bahwa dosen sudah harus mengubah metode pembelajaran ceramah secara murni tersebut dengan menyusun dan melaksanakan pembelajaran seperti yang dikemukakan Anita Lie (2007: 5) yaitu :a) Pengetahuan ditemukan, dibentuk dan dikembangkan oleh mahasiswa.b) Mahasiswa 
membangun pengetahuan secara aktif. c) Pengajar perlu mengembangkan kompetensi dan kemampuan mahasiswa. d) Pendidikan adalah interaksi pribadi di antara para mahasiswa dan interaksi antara dosen dan mahasiswa.

Sumadi Suryabrata (2006) menyatakan bahwa prestasi belajar adalah kemampuan siswa yang berupa, penguasaan pengetahuan, sikap, dan keterampilan, yang dicapai dalam belajar setelah mereka melakukan kegiatan belajar. Prestasi belajar digunakan sebagai suatu gambaran dari suatu penguasaan kemampuan para peserta didik sebagaimana ditetapkan untuk suatu matakuliah tertentu. Setiap usaha yang dilakukan dalam kegiatan pembelajaran baik oleh dosen sebagai pengajar, maupun oleh mahasiswa bertujuan untuk mencapai prestasi yang setinggi tingginya. Prestasi belajar dinyatakan dengan skor hasil tes atau angka.

Metode pembelajaran ini dipilih karena metode pembelajaran ini lebih menekankan pada keaktifan peserta didik dalam membangun konsep/pengetahuan yang dimiliki untuk mengatasi permasalahan yang dihadapi. Dalam pembelajaran ini, pendidik bersikap interaktif dalam pembelajaran dan menjadi fasilitator atau mediator dari lingkungan bagi peserta didik dalam pembelajaran. Penilaian proses pembelajaran merupakan bagian integral dalam pembelajaran, dilakukan melalui observasi terhadap unjuk kerja peserta didik, di samping dalam bentuk tes/ujian (Dandan Supratman: 2001).

Berdasarkan latar belakang masalah, tujuan dari penelitian ini adalah Untuk meningkatkan keaktifan dan prestasi belajar mahasiswa dengan penerapan metode simulasi dalam mata kuliah Teaching English For Young Learners.

\section{Metode Penelitian}

Penelitian ini merupakan penelitian tindakan kelas. Gagasan pokok penelitian ini adalah bahwa orang yang melakukan tindakan harus juga terlibat dalam proses penelitian sejak awal. Mereka tidak hanya menyadari perlunya melaksanakan program tindakan tertentu, tetapi secara emosional ikut terlibat dalam program tindakan tersebut ( Suwarsih Madya, 1994).

Setting penelitian ini adalah Program Studi Pendidikan Bahasa Inggris Fakultas Keguruan dan Ilmu Pendidikan Universitas Pendidikan Muhammadiyah Sorong. Penelitian tindakan ini dilaksanakan pada semester genap tahun 2018/2019 untuk matakuliah Teaching English For Young Learners. Penelitian ini akan melibatkan mahasiswa reguler semester VI sebanyak 30 mahasiswa. Pihak- pihak yang dilibatkan dalam penelitian ini adalah : seorang dosen sebagai peneliti utama dan sekaligus sebagai pelaku tindakan berjumlah 1 orang, dosen pengamat (observer) berjumlah 2 orang, mahasiswa sebagai subjek didik yang berjumlah 30 orang.

Teknik pengumpulan data yang akan dipergunakan dalam penelitian ini adalah observasi, wawancara, dokumentasi dan angket. Prosedur penelitian ini merupakan penelitian tindakan yang mengacu model Kemmis dan Mc Taggart (1988). Oleh karena itu, cara penelitian dilakukan melalui beberapa tahapan sebagai berikut: Tahap Perencanaan, Implementasi Tindakan, Tahap pemantauan dan evaluasi, analisis dan refleksi. Data yang akan diperoleh dari hasil penelitian ini adalah data kualitatif dan data kuantitatif sebagai pendukungnya. Analisis data dilakukan menurut karakteristik masing- masing data yang terkumpul. Dari data yang terkumpul diklasifikasikan dan dikategorikan secara sistematik dan menurut karakteristiknya. Sementara 
data kuantitatif dianalisis dengan metode diskriptif kuantitatif. Temuan ini akan digunakan untuk melaksanakan tindakan selanjutnya.

Keabsahan data dalam penelitan in dilakukan dengan teknik triangulasi. Moleong (2005: 330) mengatakan triangulasi adalah teknik pemeriksaan keabsahan data yang memanfaatkan sesuatu diluar data itu untuk keperluan pengecekan atau sebagai pembanding data itu. Penelitian ini menggunakan triangulasi sumber dan metode. Indikator Keberhasilan Tindakan adalah adanya respon yang baik dari mahasiswa, yang ditandai meningkatnya aktifitas mahasiswa, dan prestasi belajar mahasiswa pada matakuliah Teaching English For Young Learners. Secara kuantitatif diharapkan $80 \%$ mahasiswa dapat aktif dalam pembelajaran dan minimal $75 \%$ mahasiswa mendapatkan nilai di atas 70 .

\section{Hasil dan Pembahasan}

\subsection{Pelaksanaan Tindakan Siklus 1}

Pada tahap pelaksanaan tindakan ini dosen melaksanakan pembelajaran dengan metode pembelajaran simulasi. Pembelajaran dilakukan berdasarkan RPS yang sebelumnya telah disiapkan oleh peneliti. RPS tersebut terlebih dahulu telah dikonsultasikan kepada Ketua Program Studi. Selama tindakan berlangsung, peneliti dibantu oleh seorang observer mengamati secara langsung tanpa mengganggu jalannya proses pembelajaran.

Tabel 1. Tingkat Prestasi dan Aktivitas Mahasiswa pada Siklus I

\begin{tabular}{|c|c|c|c|c|c|}
\hline \multirow{2}{*}{$\begin{array}{c}\text { Tingkat Prestasi dan Aktivitas } \\
\text { Mahasiswa pada Siklus I }\end{array}$} & \multirow[b]{2}{*}{ Kategori } & \multicolumn{2}{|c|}{ Prestasi } & \multicolumn{2}{|c|}{ Aktivitas } \\
\hline & & Frekuensi & Persentase & Frekuensi & Persentase \\
\hline & & & $(\%)$ & & $(\%)$ \\
\hline $\begin{array}{l}35 \\
30\end{array}$ & Istimewa & 3 & 10 & 1 & 3 \\
\hline 25 & & & & & \\
\hline 20 & Baik & 8 & 27 & 4 & 13 \\
\hline 15 & Cukup & 10 & 33 & 22 & 74 \\
\hline 10 & Kurang & 9 & 30 & 3 & 10 \\
\hline$\square$ & Jumlah & 30 & 100 & 30 & 100 \\
\hline - Prestasi aktivitas & & & & & \\
\hline
\end{tabular}

Aktivitas masiswa diketahui dari Peningkatan kerjasama masiswa, keaktifan bertanya, keaktivan mengerjakan soal, perhatian mahasiswa ketika di kelas, dan menunjukkan minat untuk belajar TEYL. Dapat disimpulkan secara umum bahwa tingkat aktivitas mahasiswa pada siklus I ini terlihat sebagian mahasiswa masih merasa canggung untuk aktif dalam simulasi. Mereka masih terlihat stagnan sebagaimana pola belajar awal yang menggunakan ceramah, sehingga mahasiswa cenderung pasif meskipun dosen dan peneliti telah beraktivitas untuk memberikan semacam perubahan. Sehingga dapat dilihat pada aspek keikutsertaan memberi pendapat masih rendah hal ini terlihat pada ketekunan mahasiswa dalam menghadapi tugas masih rendah, yaitu ketika mahasiswa mendapat tugas untuk mengerjakan Lembar Kerja Kelompok (LKK), banyak mahasiswa yang mengeluh ketika diberi tugas oleh dosen. Sehingga dalam mengerjakan lembar kerja kelompok sebagian mahasiswa tidak mengemukakan gagasan 
masing-masing terkait dengan permasalahan yang diberikan. Pada indikator keaktifan bertanya dan menjawab pertanyaan dosen. Mahasiswa tidak langsung bertanya apabila ada masalah yan mengganjal. Dalam keaktifan menjawab pertanyaan terlihat bahwa setiap jawaban yang muncul, baik dalam kelompok masing-masing atau kelompok besar, belum ditanggapi dengan aktif oleh para mahasiswa lain sehingga harus dipandu oleh dosen dan peneliti.

Pada indikator keaktifan mengerjakan tugas yang diberikan kelompok ini terlihat bahwa tidak banyak mahasiswa yang ingin mendalami lebih jauh materi yang dipelajari, hal ini terlihat dari kurang aktifnya mahasiswa untuk bertanya pada dosen. Mahasiswa juga belum terlihat antusias dalam beraktivitas menyelesaikan tugas yang diberikan oleh dosen. Perhatian siswa pada materi pembelajaran juga masih kurang. Siswa ada yang mengobrol dengan temannya ketika simulasi berlangsung. Mereka membicarakan hal-hal di luar materi pelajaran.

Keaktifan yang ditunjukkan dengan minat untuk belajar TEYL diketahui bahwa belum banyak mahasiswa ingin berprestasi sebaik mungkin pada kelompoknya, sehingga masih ada mahasiswa yang tidak bersungguh-sungguh saat mengerjakan soal diskusi dalam kelompoknya hal ini masih terlihat saat pengerjaan lembar kerja kelompok dalam satu kelompoknya masih ada mahasiswa yang mengobrol dengan teman satu kelompoknya.

\subsection{Pelaksanaan Tindakan Siklus II}

Aktivitas mahasiswa diketahui terjadi peningkatan kerja sama mahasiswa, keaktifan bertanya, keaktifan mengerjakan soal, perhatian siswa ketika di kelas, dan menunjukkan minat untuk belajar TEYL. Berikut ini ditunjukkan kategori hasil tindakan terhadap prestasi belajar dan aktivitas mahasiswa pada siklus II ini dapat dilihat pada tabel 2.

\section{Tabel 2 . Tingkat Prestasi dan Aktivitas Mahasiswa Pada Siklus II}

\begin{tabular}{ccccc} 
& \multicolumn{2}{c}{ Prestasi } & \multicolumn{2}{c}{ Aktivitas } \\
Kategori & Frekuensi & Persentase & Frekuensi & Persentase \\
& & $(\boldsymbol{\%})$ & & $(\%)$ \\
Istimewa & 5 & 17 & 4 & 14 \\
& & & & \\
Baik & 12 & 40 & 23 & 76 \\
Cukup & 12 & 40 & 2 & 7 \\
Kurang & 1 & 3 & 1 & 3 \\
Jumlah & 30 & 100 & 30 & 100
\end{tabular}

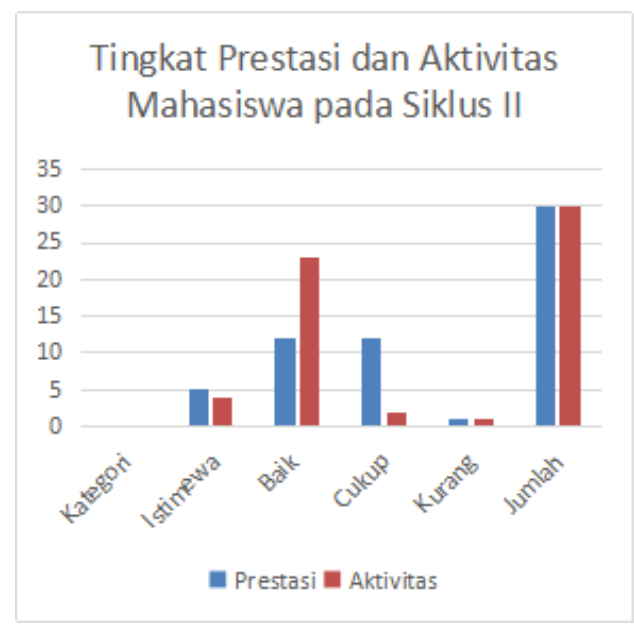

Dapat disimpulkan secara umum bahwa tingkat aktivitas mahasiswa pada siklus II ini terlihat sebagian mahasiswa sudah kelihatan aktif dalam simulasi. Dengan permainan yang mengaktifkan seluruh mahasiswa, mereka lebih terlihat serius dalam mengerjakan simulasi. 
Pada indikator keaktifan bertanya dan menjawab pertanyaan dosen. Mahasiswa sudah langsung bertanya apabila ada masalah yan mengganjal. Mereka juga sudah diskusi dalam kelompok besar dan kecil.

Pada indikator keaktifan mengerjakan tugas yang diberikan kelompok terlihat bahwa cukup banyak mahasiswa yang ingin mendalami lebih jauh materi yang dipelajari, hal ini terlihat dari semakin aktifnya mahasiswa untuk bertanya pada dosen. Mahasiswa juga belum terlihat semakin antusias dalam beaktivitas menyelesaikan tugas yang diberikan oleh dosen. Namun masih ada beberapa mahasiswa yang terlihat tidak aktif berdiskusi dalam kelompok. Perhatian mahasiswa pada materi pembelajaran juga sudah cukup. Mahasiswa ada yang mengobrol dengan temannya ketika simulasi berlangsung. Tidak terlihat mahasiswa mengantuk atau bercakap-cakap dengan temannya.

Keaktifan yang ditunjukkan dengan minat untuk belajar TEYL diketahui bahwa banyak mahasiswa ingin berprestasi sebaik mungkin pada kelompoknya, sehingga mahasiswa bersungguh-sungguh saat mengerjakan soal diskusi dalam kelompoknya.

\section{Pelaksanaan Tindakan Siklus III}

Hasil pengamatan yang dilakukan untuk prestasi belajar mahasiswa diukur pada setiap akhir siklus. Sedangkan untuk aktivitas mahasiswa diukur atau dapat dilihat setiap pertemuan per siklus. Di bawah ini hasil pengamatan yang dilakukan oleh peneliti dan dosen selama proses pembelajaran berlangsung pada siklus III mengenai prestasi belajar mahasiswa dan aktivitas mahasiswa adalah sebagai berikut:

\section{Tabel 3 . Tingkat Prestasi dan Akivitas Mahasiswa Pada Siklus III}

\begin{tabular}{|c|c|c|c|c|c|}
\hline \multirow{2}{*}{$\begin{array}{c}\text { Tingkat Prestasi dan Aktivitas } \\
\text { Mahasiswa pada Siklus III }\end{array}$} & \multirow[b]{2}{*}{ Kategori } & \multicolumn{2}{|c|}{ Prestasi } & \multicolumn{2}{|c|}{ Aktivitas } \\
\hline & & Frekuensi & Persentase & Frekuensi & Persentase \\
\hline 35 & & & $(\%)$ & & $(\%)$ \\
\hline 30 & Istimewa & 5 & 16 & 9 & 30 \\
\hline 25 & & & & & \\
\hline 20 & Baik & 18 & 60 & 18 & 60 \\
\hline 15 & Cukup & 7 & 24 & 3 & 10 \\
\hline $\begin{array}{r}10 \\
5\end{array}$ & Kurang & 0 & 0 & 0 & 0 \\
\hline $\begin{array}{l}5 \\
0 \\
\end{array}$ & Jumlah & 30 & 100 & 20 & 100 \\
\hline - Prestasi $\mathbf{~ A k t i v i t a s ~}$ & & & & & \\
\hline
\end{tabular}

Aktivitas siswa diketahui dari Peningkatan kerjasama siswa, keaktifan bertanya, keaktivan mengerjakan soal, perhatian siswa ketika di kelas, dan menunjukkan minat untuk belajar TEYL. Dapat dilihat pada siklus III ini berdasarkan aspek atau indikator yang diamati, terlihat bahwa tingkat aktivitas mahasiswa sebagian besar berada pada kategori tinggi yaitu sebanyak 18 siswa (60\%). Sementara itu, 9 (30\%) mahasiswa berada kategori sangat tinggi. Sehingga $90 \%$ mahasiswa berada pada ketori tinggi dan sangat tinggi . 
Dapat disimpulkan secara umum bahwa tingkat aktivitas mahasiswa pada siklus III ini terlihat sebagian mahasiswa mahasiswa sudah aktif dalam simulasi. Dengan permainan yang mengaktifkan seluruh mahasiswa, mereka lebih terlihat serius simulasi. Pada indikator keaktifan bertanya dan menjawab pertanyaan dosen. Mahasiswa sudah langsung bertanya apabila ada masalah yan mengganjal. Mereka juga sudah diskusi dalam kelompok besar dan kecil. Dosen sangat menghargai pendapat mahasiswa dan diberi reward berupa pujian bagi mahasiswa. Pada indikator keaktifan mengerjakan tugas yang diberikan kelompok terlihat bahwa cukup banyak mahasiswa yang ingin mendalami lebih jauh materi yang dipelajari, hal ini terlihat dari semakin aktifnya mahasiswa untuk bertanya pada dosen. Mahasiswa juga belum terlihat semakin antusias dalam beaktivitas menyelesaikan tugas yang diberikan oleh dosen. Namun masih ada beberapa mahasiswa yang terlihat tidak aktif berdiskusi dalam kelompok. Perhatian siswa pada materi pembelajaran juga sudah cukup. Siswa tidak ada yang mengobrol dengan temannya ketika simulasi berlangsung. Tidak terlihat siswa mengantuk atau bercakap-cakap dengan temannya

Keaktifan yang ditunjukkan dengan minat untuk belajar TEYL diketahui bahwa banyak mahasiswa ingin berprestasi sebaik mungkin pada kelompoknya, sehingga mahasiswa bersungguh-sungguh saat mengerjakan soal diskusi dalam kelompoknya. Dari siklus ke siklus diketahui terjadi peningkatan aktivitas dan prestasi belajar mahasiswa. Pada siklus III diperoleh data bahwa mahasiswa antusias dalam pembelajaran tersebut, sehingga hasil penelitian ini sudah dianggap cukup karena telah memenuhi kriteria yang ditentukan yaitu adanya respon yang baik dari mahasiswa, yang ditandai meningkatnya aktifitas mahasiswa minimal 80\% mahasiswa aktif dalam proses pembelajaran, dan prestasi belajar mahasiswa pada matakuliah TEYL minimal $75 \%$ mahasiswa dapat menguasai $70 \%$ materi yang ditandai dengan nilai di atas 70 .

Penerapan metode pembelajaran simulasi pada matakuliah TEYL membuat mahasiswa menjadi lebih aktif dan terlibat dalam proses pembelajaran sehingga konsep yang didapat akan lebih mudah diingat serta membantu dalam melatih keterampilan mahasiswa. Hal yang terpenting lainnya yaitu dengan metode pembelajaran ini, penyampaian materi menjadi lebih menarik dan tidak membosankan.

\section{Kesimpulan dan Saran}

Berdasarkan pembahasan yang telah dilakukan pada bab sebelumnya secara umum dapat disimpulkan bahwa penerapan metode pembelajaran simulasi dapat meningkatkan prestasi belajar dan aktivitas pembelajaran. Adapun kesimpulan secara rinci adalah Penerapan metode pembelajaran simulasi dapat meningkatkan aktifitas mahasiswa. Hal ini ditunjukkan dengan peningkatan persentase keaktifan yang diperoleh dari lembar observasi dan angket. Terjadi peningkatan aktivitas belajar dari siklus I ke siklus II, dan dari siklus II ke siklus III. Penerapan metode pembelajaran simulasi dapat mengoptimalkan prestasi belajar siswa. Prestasi belajar siswa mengalami peningkatan dari prestasi belajar siklus I ke siklus II, dan dari siklus II ke siklus III.

Adapun saran yang dapat diberikan berdasarkan hasil penelitian dan pembahasan adalah sebagai berikut: 1) Dosen diharapkan dapat mempelajari pedoman pelaksanaan simulasi dalam kelas. Melalui pelaksanaan pembelajaran simulasi dengan baik mahasiswa akan lebih berhasil dalam menguasai materi pelajaran sehingga siswa termotivasi dalam mengikuti kegiatan pembelajaran dan aktif dalam tugas yang diberikan oleh gurunya. 2) Dosen dapat menggunakan metode simulasi ini karena memiliki keistimewaan yaitu menggabungkan antara ceramah, 
diskusi, dan demonstrasi yang dapat meningkatkan aktivitas ketika pembelajaran yang berlangsung. Keterbatasan penelitian ini adalah: Perlu waktu yang cukup banyak untuk menggunakan model simulasi. Apabila metode ini digunakan terus menerus mahasiswa akan mengalami kebosanan sehingga perlu variasi dalam menggunakan metode pembelajaran di kelas.

\section{Daftar Pustaka}

Cameron, L. (2001). Teaching Language to Young Learners. Cambrigde: Cambridge University Press.

Lie, Anita. 2007. Mempraktekkan Cooperative Learning di Ruang - Ruang Kelas. Jakarta : Grasindo.

Hamalik,Oemar, 2001. Proses Belajar Mengajar. Jakarta: Bumi Aksara Suryabrata,Sumadi. 2006.

Panduan Penelitian Tindakan.

Yogyakarta : Lembaga Penelitian IKIP Yogyakarta.

Kemmis S dan Mc Taggart . (1988 ). The Action Research Planner. Deakin: Deakin University Press.

Moleong, Lexy.J.. 2005. Metodologi Penelitian Kualitatif. Bandung : PT Remaja Rosdakarya

Sardiman AM. (2003). Interaksi \& Motivasi Belajar Mengajar, Jakarta: Rajawali Press 